\title{
Article
}

\section{Out of the Ordinary}

Monsters as Extreme Cases Among the Bugkalot and Beyond

\author{
Henrik Hvenegaard Mikkelsen \\ Independent Scholar
}

\section{Abstract}

This article challenges the tendency, both academic and popular, to assign 'monsters' the status of the radical Other: of that which we are not. This widespread inclination to understand monsters as agencies breaking into the ordinary ignores what I propose to call the 'radical sameness' of monsters: that is, the multiple ways in which monsters appear to embody the features of what people or society could, potentially, become. To develop this argument the article takes its point of departure in ethnographic research carried out among the Bugkalot of Northern Luzon. Exploring the quasi-mythical character known as the mansasadile, I argue that this figure exposes the potential dangers of individuality and current social change; with the growth of paid labour in the farming industry, the possibility is emerging that the young men will detach themselves from their families. The mansasadile shows the situation whereby the monstrous, rather than being the 'radical other' that intrudes into the everyday, is the monstrous that erupts out 'out of the ordinary'.

\section{Keywords}

monsters, Bugkalot, psychopaths, Philippines, comparison

According to one of the most dominant narratives of today we live in a time of monsters (Žižek 2012). Recently, secretary general of Amnesty International, Salil Shetty, stated that 'the politics of demonization', i.e. 'the cynical use of "us vs them" narratives of blame, hate and fear [has taken] on a global prominence to a level not seen since the 1930s' (Amnesty International 2017). Divides between political fractions are growing in nations across the globe: opponents are being dehumanized, adversaries are being 'othered' (Carothers and O'Donohue 2019). Such narratives of growing sectarianism add to a general sense of precariousness (Boxel 2020) and affirm that ascribing to others the identity of the less-than-human remains a potent political instrument. 
The term 'monster' is often applied when someone has, by their own horrific actions or convictions, abdicated their humanity. When Josef Fritzl, the Austrian man who had kept his daughter locked up for decades, emerged on TV-screens and front covers of magazines across the globe, the picture of the elderly man was often accompanied with the word Monster. Thus, while most monsters are either located in faraway times or in faraway places - or in the world of fiction - it is clear that the monster is not only an epithet applied to that which is not here. In trying to understand what made Fritzl particularly monstrous in the public eye, one could turn to John Borneman's work on incest and child molesters in Germany (Borneman 2015). Borneman refers to the 'double-sided nature of abuse'. For instance, in relation to a mother who has an incestuous relationship with her child. For isn't it the case, Borneman asks, that the relationship between mother and child is premised on an early seduction of the child? 'Without such early seduction', he writes, 'children develop a limited capacity for emotional growth and vulnerable attachments to others' (Borneman 2015, 49). The child molester, Borneman suggests, thereby engages in an extreme, abject version of a practice that is culturally encouraged. What is, perhaps, so hard to stomach, is that the child molester is not something radically different, but a more extreme version of us. Consequently, he continues, the entering of such stories into public discussions is a response to a 'deeper need present in audiences, which is to bring them into an experience of unconscious proximity with something dark, powerful, mysterious, undefinable, wanted and not wanted at the same time' (Borneman 2015, 49).

The implicit question I pursue is what kind of cultural critique emerges when you analyse society through its most extreme, monstrous cases? I take my cue from Borneman in order to show the double-sided nature of particular monsters. I will argue that such monsters may best be understood as 'extreme cases'. Yet, they are not 'extreme' by being non-representative outliers, but rather by being radical realizations of particular ideals and potentials. The monsters that will be explored in this article may be considered the consequence of current trends, the realization of our desires.

The 'monstrous' is the term I apply to capture the phenomenon whereby something is imagined as radically other; yet, as I will show, it derives its monstrosity from being the very opposite - namely, the radically same. It is within the tension between the foreign and the familiar that we find the semi-mythical figure known among the Bugkalot of Northern Philippines as the mansasadile. The mansasadile was a powerful image in present-day storytelling that caused both fascination and trepidation among my interlocutors. According to the stories I heard, the mansasadile were in most cases unmarried men who lived in isolated and remote areas of the mountains. However, others were talked about in ways that conjured up images of boisterous, destructive forces. Whereas the word mansasadile was sometimes used as an adjective, simply meaning 'autonomous' and thereby referring to individuals marked by an impressive amount of independence, a person 
could also be a mansasadile ${ }^{1}$. Rather, the word was used colloquially as a descriptor for a person who was utterly indifferent to other people and who was impervious to feelings of shame.

Through this case, I seek to show how viewing an agency as monstrous becomes a way of dealing, culturally, with threats that arise within society. In other words, while monsters as radical others have attracted vast amounts of academic attention, in this article I wish to provide an ethnographic entry point into situations where monsters may be seen to gain their monstrosity from the extreme actualization of what is, in fact, culturally encouraged. I seek to show that the mansasadile may be considered the embodiment of ideals concerning masculine autonomy ideals that have actually become attainable with the emergence of industrial-scale agriculture: While autonomy, according to all ethnographic accounts, has been celebrated among the Bugkalot through, especially, headhunting practices, it has recently become possible for young Bugkalot men to accumulate financial capital and actually sever themselves from the obligations of kinship. Autonomy has become attainable. My point in this survey is not to be exhaustive, but rather to propose that the mansasadile is ultimately a paradoxical state of being that establishes a critical role in relation to Bugkalot masculinity. The mansasadile, I will argue, is a special mode of being that is part of every man as potentiality and which, ultimately, portrays the decomposition of the community as a whole.

\section{A Man in the Mountains}

During a wedding celebration in a small village in the mountain interior of the Sierra Madre Mountains, an elderly man named Táno appeared. Just before noon, after the wedding ceremony had ended, people spread out on the open area by the church in the northern end of the village. Most of them gathered in small groups in the grass, chatting and enjoying the food that was being passed around. The few scattered benches were packed with people of all ages sitting shoulder to shoulder. A nervous space started to build up on the far eastern end of the area and soon those who had been sitting there left the area - except for Táno, who appeared to have caused the subtle unrest.

He had shown up just after the ceremony. He was unaccompanied, which was unusual given his apparent advanced age. But that was not the only unusual thing about him. His ragged jeans and t-shirt were covered in mud, and his long hair and beard were tangled and knotted. Whereas all the other visitors had washed themselves immediately upon arrival - or, preferably, as they crossed the river before entering the village - this person did not seem to pay any attention to the mud that began to crust in the sun and fell from his clothes in flakes.

\footnotetext{
1 The latter use of the word could be derived from other Austronesian languages, where adil means 'impartial.' It is likely that the term mansasadile-'impartial man'-could thereby have been, traditionally, a noun that designated a specific type of leadership or political mediator.
} 
The man's presence was remarkable. He was treated with a kind of awe that I did not witness in relation to any other person during my fieldwork. I noticed that a village elder brought him rice and water without uttering a word to him and without receiving even a nod in reply. The man took the food without any reaction. Though he made no attempt to communicate with the other visitors he attracted an immense, yet unspoken, amount of attention.

I saw Táno every few months in the village and, like at the wedding, he never approached anyone. In fact, it seemed as if he had no particular purpose in coming to the village. On each of his visits, I asked my friends to come along and help me talk to him, and every time they stalled and came up with excuses to avoid this task. After much pressure, a local schoolteacher named Wagsal explained to me why he felt uncomfortable around the man. He said to me:

When Táno is here, everyone is alert. You see the old men, one moment they chew betel nut, they sit close to the fire, and they talk. Then it is as if they have noticed something. They sit up and they look very vigilant. They cannot relax. It is like that when Táno comes here. They do not know what to do. It stands still like a tree; that is because it is mansasadile, but then, suddenly, it might attack, like this!

Wagsal made a dramatic cutting motion with his finger across his throat and continued

He once had a family, cousins. But no more. There is no one in his life. He is completely alone. It is as if everything - you, me, everything - is no longer here. Who knows what kind of thoughts are in its head? I cannot see its mind. No one can. No one can understand that kind of mind.

Wagsal referred to Táno as it rather than as he, which amplified the awareness that we were talking about something that was extraordinary. The term Wagsal applied to Táno, mansasadile, was a word that reappeared in many stories. However, this was the first and only time it was applied to a person who was not first and foremost a character living in the past or a creature living deep in the forest. Yet, people talked about him in exactly the same way they talked about the ones living in the past. These stories accentuated various forms of unpredictability and unspecified violent acts that opposed the ungovernable mansasadile to the ordinary conditions of life in the village.

\section{Nightworlds}

What makes something monstrous? Much literature, from Aristotle's time to the present, has stated that the monster is that which disrupts categories of taxonomy (Asma 2009, 125). This has, for instance, made the monstrous an often-used ana- 
lytical lens in gender studies as it allows scholars to gain insight into the western, cultural response to individuals who transgress conventional binary gender categories (Chamberlain 2019, Mubarki 2014). This has also led anthropologists to draw connections between the monstrous and Mary Douglas' analysis of cultural representations of pollution: nature and culture disordered (Kapferer 1983). Monsters that transgress categories are widespread within Western fiction, where many of the classical monsters - Dracula, Mr. Hyde, Frankenstein's monster, etc. - tend to be category-crossing hybrids. As the philosopher Judith Halberstam points out, these monsters 'metaphorized modern subjectivity as a balancing act between inside/outside, female/male, body/mind' (Halberstam 1995, 1). Yet, she argues, a shift has taken place in what constitutes a monster - especially compared to the famous monsters of the $19^{\text {th }}$ century gothic fiction. The monster of today, she argues, is all body: it is a monster consisting only of surfaces. This is the monster of Bret Easton Ellis's book American Psycho: a shallow creature becoming the extreme example of a world consumed in shallow consumption.

The point is, of course, that what constitutes the monstrous is not stable. Monsters are shaped by the cultural ontology within which they exist - and this is the reason why monsters are of interest to anthropologists. This article is informed by the assumption that exploring how the monstrous manifests locally and documenting the specific ways in which people relate to monsters, reveal how people understand themselves, their world and their position within it (Musharbash 2014). One can learn a lot about a society by looking at its world of monsters, witches, demons and other agencies that threaten to overwhelm it. For instance, David Graeber notices that the striving for consensus in egalitarian societies often sparks a 'spectral nightworld inhabited by monsters, witches or other creatures of horror'. Thus, he argues, 'it is the most peaceful societies, which are also the most haunted, in their imaginative constructions of the cosmos, by constant spectres of perennial war' (Graeber 2004, 25). Anthropology has provided nuanced understandings of the geographically confined, emic ways in which people engage with and transform social relationships based on collective understandings of deviancy and evil (Kapferer 1983, Comaroff and Comaroff 1999, Kuldova 2017).

At the same time, the monstrous is not simply culturally relative. As I wish to show in the following, one may detect basic mechanisms that work across cases. By making an ethnographic leap from the Bugkalot ontology to the western psychiatric category of the 'psychopath', I engage in a form of comparison that, by juxtaposing seemingly dissimilar phenomena, may re-open new insights into the qualitative resemblances between what was previously considered to belong to radically separate domains (Buband and Willerslev 2015). Applying this approach to monsters, this article enters a terrain that has attracted scarce attention from anthropologists. With few exceptions (e.g. Stevens 2008) anthropologists have contributed little comparative research into how people engage with monsters in a way that allows conversations to take place between phenomena that dwell at the fringes of what western epistemology identifies as monsters. It is indicative, for example, that in the current public debates about alleged dehumanization of public opponents and 
the growing political gaps in society, anthropologists have largely been absent. Perhaps the main reason for this is that anthropologists have not created a shared vocabulary for addressing monstrosity across cultures. Indeed, while a number of ethnographic accounts focus on different types of (ritual) engagement with monstrous, non-human agencies (Comaroff and Comaroff 2002; Geschiere 1998) and the spectacular performances that surround their containment and expulsion (Mikkelsen 2018), the theme of monsters tends usually to be broached more or less incidentally, in the course of discussing other topics, such as the political efficacy of ritual (Turner 1967). Even in the copious ethnographic literature on witches, connections are rarely drawn to other categories of monsters, and cross-cultural comparisons mainly emerge as a feature of a more abiding debate about the nature of rationality (Evans-Pritchard 1937; Bubandt 2014; Geschiere 2013).

While a broader anthropological theorization of monsters remains on the horizon, for now we can conclude that paying close attention to the monsters that inhabit any given society provides a fruitful lens for learning about local anxieties and the society as a whole. In this sense, monsters enable us to talk about common features of the non-monstrous. This is what the philosopher Judith Halberstam refers to as gothicization, i.e. the identification of bodies in terms of what they are not - of what is not 'native' (Halberstam 1995, 19). Thereby, monsters serve the function of 'stabilizing sameness' by allowing the imaginary intrusion into the common world of racial pariahs, outcasts and sexual outsiders (Halberstam 1995, 20).

Similarly, beyond the world of literary studies, Susan Behuniak's research on Alzheimer's disease (AD) shows that people's strong emotional response to AD is buttressed by the social construction of people with $\mathrm{AD}$ as zombies. As she points out, there is 'obvious and uncomfortable overlap between the characteristics of zombies and persons with AD. The slow shuffle, the inarticulate moans, the relentless walking, the dishevelled appearance' (Behuniak 2011, 79). To Behuniak, the connection drawn between zombies and AD patients helps to explain the origins of the intense form of stigma applied to AD (Behuniak 2011, 75). She argues that the tendency to think of $\mathrm{AD}$ as a kind of 'living death' is problematic as it commands fear before sympathy. Since George A. Romero's zombie trilogy, the image of the decomposing creature, lumbering forward to feed on people who still haven't been infected is now firmly established in our popular imagination. Thus, one may speculate, talking about people with $\mathrm{AD}$ as zombies could mean relocating the terrible disease to a world where zombies, at least in a Western context, typically roam: namely, the world of fiction. It thereby becomes a way of not having to deal with the fact that $\mathrm{AD}$ is on the horizon for all of us if we live long enough.

Behuniak's research suggests that not only may the monster label be a way of 'othering' others - it may offer a way to other certain, potential areas of oneself. To help us pursue this idea, I will turn to the mansasadile. The mansasadile, I argue, is the ideal of masculinity taken to its radical conclusion, thereby providing a per- 
spective on the precarious potentiality of the Bugkalot man at a particular historical juncture marked by swift social change.

\section{Sameness and equality}

The Bugkalot ${ }^{2}$ live in the mountains of Eastern Luzon. They were gradually drawn into the administrative nexus of the Philippine state only by the early 1980s. Yet it was not until the turn of the millennium, with the gradual development of the first highland roads in the area, that this development intensified and started to have a far-reaching effect on the mountain communities. With the roads, the inhabitants of the area gained a relatively easy access to the lowland. Within years, traditional forms of horticulture changed to an economy based on specialized agriculture that was closely tied up with the wider Philippine economy. As a result, hunting - and rural subsistence in general - suffered a swift and perhaps irreversible decline. From 2010 the trails and dirt roads were gradually upgraded to asphalt roads and within a few years it became possible to reach most communities by truck even during the rainy season. A 2009, when I began my first fieldwork in the mountains, few people had considered this to be possible. The sudden access to land had brought about immense migration to the area of farmers from the adjoining provinces. The deforestation was taking place with breath-taking speed; a vast area of seemingly impenetrable primary forest was removed in just months. This sometimes gave rise to surreal experiences: What was first thought of as a vast expanse of wilderness proved to be merely a shallow, green curtain; as these ill-fated patches of forest were cleared, views were suddenly opened up to denuded mountaintops and distant horizons of newly prepared farmland - or, more often, to exhausted stretches of barren land, red clay and rocks, for as far as the eye can see.

During the evenings the inhabitants in the different communities could now see the fires from other villages in the distant expanses of the valley floor. Though some of the communities had existed for centuries, their recent visual emergence was shaping a new sense of relatedness among the Bugkalot. Thus, while the deforestation made hunting more difficult and had started to cause annual mudslides, it was widely considered a positive development, since it opened up and structured the land in new ways: what had previously been almost impenetrable vegetation was turned into patios, gardens, a traversable landscape that represented the prospect for further development of the area. The villagers had started to ride down to the lowland on a monthly basis on the vegetable trucks to see relatives, buy consumer goods and visit health clinics. In other words, I was a guest in the village at a time of unprecedented social and ecological transformation.

\footnotetext{
2 When I use the term 'Bugkalot', I resort to ethnographic shorthand for the Bugkalot-speaking inhabitants of the Caraballo and Sierra Mountain Range of northern Luzon where I carried out fieldwork in 2009-2010.
} 
Even though the chance of shooting a deer or a boar was becoming less likely, the men continued to enter the remaining forest in the mountain interior on hunting trips, laob, that could last for days. Hunting was a collective enterprise, which was arranged through situational authority; a leader, the gemapó, emerged just for the particular context of the hunt. At the end of the hunt the function of the gemapó came to an end. Accordingly, the gemapó would not be praised if the hunt was successful, nor would he be assigned responsibility if it failed - which was often the case. The hierarchical leadership developed within, and was accepted within, the context of the hunt and would be dissolved on returning to the village.

In Michelle Rosaldo's extensive writings on the Bugkalot ${ }^{3}$ she often argues that the Bugkalot, unlike the individualized subjects of the West, 'assume that persons want to be not different but equivalent or "the same"" (Rosaldo 1983, 137). Tying this to an indigenous, egalitarian ideology of the autonomous person, she argued that the striving for sameness and the safeguarding of individual autonomy restrained 'conflict-breeding inequalities' in the communities. Thus, the Bugkalot never required 'punishment for wrongs' or sought 'displays of suffering and remorse in atoning for untoward violence' (Rosaldo 1983, 144). Her informants, she argued, employed the image of equal men traveling together along a narrow path in line to tease out a particular Bugkalot ethos. Furthermore, Rosaldo saw ideals of sameness as an engine that created social action. The striving for sameness, she argued, animated men to engage in various endeavours in their attempt to reach what others among their peers had reached. When the ideals of sameness were breached, that is, when someone in a group of peers had reached a higher level of social esteem through, for instance, having participated in a headhunting raid, the other men became unable to 'work dependably, think clearly, or enjoy the company of kin because their "shame" brings sullenness, distraction, and ill-ease' (1983, 146).

While this discourse on egalitarianism was widely upheld in daily speech during my fieldwork, 40 years after Michelle Rosaldo wrote about the Bugkalot, it was also clear that the introduction of new industrial scale farming meant that, very soon the self-image of a 'people of equals' would be undermined.

\section{Unsold Rice}

Bugkalot egalitarianism was not the 'fierce egalitarianism' that has been studied among hunters and gatherers elsewhere. Richard Lee argued that among the ! Kung of Botswana, egalitarianism is 'fiercely' maintained (Lee 1969; 1988). The social instrument most often applied in this regard is public ridicule. If a person fails to show proper humility, the rest of the group will poke fun at that person

\footnotetext{
3 In the ethnographic literature, the people who dwell in the Bugkalot have commonly gone under the name llongot (e.g., M. Rosaldo 1980). This exonym comes from the word e'gongot, which means 'from the wilderness.' The name is considered inappropriate and incorrect by many of the people to whom the term is ascribed.
} 
mercilessly until proper humility is shown. Also, whenever a hunter returns from a successful hunt and shares the meat with the others, he makes every effort to explain that the animal was in fact skinny and worthless. If he fails to do that, others will do it for him and make fun of him in the process. One of the !Kung elders explained to Lee that the purpose of 'insulting the meat' is to avoid an outcome in which the hunter 'comes to think of himself as a big man, and he thinks of the rest of us as his inferiors. We can't accept this. We refuse one who boasts, for someday his pride will make him kill somebody. So we always speak of his meat as worthless. In this way we cool his heart and make him gentle' (Lee 2003, 54).

Though I witnessed similar practices among the Bugkalot, such direct ridicule was exclusively directed toward the youth. And rather than being ignited by a widespread desire for egalitarian stability per se, as among the !Kung, the opposite in fact seemed to be the case. Talking down to the youth was a way through which adult men made themselves visible, lifting themselves in an appropriate fashion within a social hierarchy.

The young men were constantly laughed at, humiliated and referred to scornfully as baak. This Ilocano word, which also means 'old or unsold rice,' referred to young men who had not managed to find a spouse. This was, in fact, the reality for almost all the young men in the village that I lived in. The women tended to marry into the communities of migrant farmers from other provinces that bought farming land across the mountains.

Everyone was uncertain what the future would hold for the young men. They had all found employment on the vegetable trucks, in the fields or occupied themselves with carabao logging. ${ }^{4}$ This type of work offered the highest returns on labour of all the income-generating options in the mountains. The combination of daily humiliation and the new-found access to financial means made people reflect that, perhaps soon, the young men would all leave the villagers. For now, however, the adolescents were rapidly increasing their social isolation through drinking, picking quarrels, and making themselves obnoxious.

\section{Personhood and autonomy}

The Bugkalot imagine the life trajectory as a gradual contraction. This means that from the outset, in childhood, one is embedded in the flux and chaotic forces of the world (Mikkelsen 2016). However, with age a person gradually separates himself from chaos (gongot) through the accumulation of beya-autonomy. In relation to the male sphere, this is a process which entails the development of the man's capacity to act. While beya should, ideally, find its highest form in the Elder, it has a limit. When reaching a certain, unspecified intensity, beya crosses a threshold, at

4 This backbreaking and dangerous work was carried out by groups of young men and consisted inillegally_cutting down trees and hauling the timber with the help of domesticated buffalos (carabaos), to the nearest waterway. Subsequently, the group of men would raft the boards to the lowland sawmills. 
which point it is no longer beya. At that moment beya switches from being an autonomy that evaluates itself in relation to others to being fundamentally detached. This topic was commonly broached in relation to the type of ritual headhunting, ngayó that had formed an integral part of life among the Bugkalot until the 1970s. My informants explained how during 'the days of cutting' (magon ma pa momotog), all social life revolved around the desire of young men to achieve the same recognition as those among their peers who had taken heads (Mikkelsen 2017; 2013, Mikkelsen and Søgaard 2015).

When the elders talked about headhunting, they rarely dwelled with the part of the story that had to do with the head. It was cut off and thrown to the ground an act that ended the deed. One thing they did bring back from the raids were different other body parts of their victims. The purpose of this act was to make the children accustomed to, and emotionally unaffected by, the sight and smell of human blood - to prepare them for their own future acts of violence. It thereby created a continuity between generations.

Yet, it was widely acknowledged that exposing children to blood also involved the risk that children would, eventually, become so unaffected that they lost all interest in their peers. But not only that. A boy could reach a level of autonomy where all the threads that connected him to the surrounding world, that twine from person to person, all the kinships he extended to not only family, but to pets and game, even to the fish in the river and birds of the sky - all, all, had dissolved. He was severed from all ties. This monstrously accelerated form of beya gave shape to the mansasadile.

While ngayó had always been arranged as part of a group endeavour under the supervision of Elders, in reality there were many examples of ngayó in which the 'the cutter' (momotok) carried out the killing unescorted. This was considered a fundamentally non-sensical act, which my informants struggled to comprehend. Firstly, if the aim of headhunting was to level yourself in relation to your peers, to gain their recognition, what would be the reason for going out without your peers, i.e. without anyone to verify that the act had been carried out? Secondly, the mansasadile did not ask the Elders for permission before going out, as customs required. By going out on his own initiative, the momotok circumvented the Elders and ran the risk of being excluded from the community. Why would anyone run such a risk? But it was exactly this enigmatic behaviour that made the mansasadile a powerful image within present day storytelling. In relation to headhunting, the mansasadile, which was always referred to with the pronoun 'it' rather than 'he', differentiated itself from ordinary men by acting on its own. However, the figure of the mansasadile was emerging in a variety of contexts beyond the context of ritual violence. It was being applied to a wide range of situations where society was breaking up. 


\section{Talikaw, the Mansasadile}

In many cases, talking about the mansasadile appealed to different traumatic registers in Bugkalot history, such as the common experience of being raided by headhunting parties in the past. But during the time of my fieldwork, 40 years after the end of headhunting, the mansasadile had begun to emerge in a variety of different conversations.

One mansasadile in particular, Talikaw, had made an imprint on the collective history of the Bugkalot. Even the young people, who had not yet been born when Talikaw terrorized the villages in the eastern parts of the mountains, knew its name. It was in fact remarkable how often Talikaw made its way into various unrelated conversations. Talikaw had been a fully-grown man at the end of World War II. In those days, Talikaw was among the most uncompromising participants in the massacres of the Japanese soldiers who had sought refuge from the U.S. forces in Bugkalot territory (Mikkelsen 2018). During the late 1970s Talikaw took several wives and thus conflicted with the rules of monogamy as it was encountered in both missionary dictums and customary conjugal practices. Talikaw did not ask the women's families for permission and, as I was told, the families did not dare to oppose Talikaw. Most infamously, Talikaw had represented the Bugkalot as their 'chief' in order to secure a contract with a logging company during the 1980s. This was the source of its financial wealth.

My friend Simon, a Pentecostal pastor, told me one of the most popular stories about Talikaw:

Even the police feared It. They came to the house. Talikaw was sometimes violent and carried a gun in its belt. It brought this gun everywhere. And so, one day the police came to the house to get it. I think they wanted to put Talikaw in jail. But Talikaw refused to come with them. Talkikaw stood there in the door with the gun and so, you know, the police were afraid. Maybe they were just young men. Did they want to get killed because of this? No, of course not. So, they left again. I think they came back again, but the same thing happened. Talikaw didn't even try to run away. It just stood in the door and looked at them. Yes, Talikaw was completely without fear. Then what can you do?

The rhetorical question after stating that Talikaw was without fear ('Then what can you do?') indicates that 'fear,' to Simon, was tied up with predictability. Having no fear, on the other hand, meant that a person could not be expected to act in any predictable way. One could also hypothesize that by the broad 'you,' Simon was not talking only about the policemen who were assigned with the ill-fated assignment of bringing Talikaw in; 'you' referred to society in general. If so, Simon's account points to how the Bugkalot communities had no institutions that could deal with or penalize a truly fearless (and thus unpredictable) agency, a mansasadile. 
The mansasadile pointed to an inherent conflict in the Bugkalot power structure, namely, that the autonomy of a man, when taken to its extreme, could render the man into a monstrous it and tear society apart. The ability of the mansasadile to remain fundamentally unaffected by its surroundings - its imperviousness to any form of pressure - were the features of the mansasadile that especially fascinated my informants. Talikaw posed a threat to a form of social organization, which relied on the ability to systematically eliminate social distinctions of wealth, power, and status through the mechanism of social exclusion (Woodburn 1982). In a sense, Talikaw was already living outside of the social domain within which exclusion constituted a threat.

As a hyperbolic figure, the mansasadile was the antithesis of social life, as it exposed the potential dangers of individuality and current social change at a time when young men were accumulating wealth. The social mechanism of shame and envy, which was said to be a key force of human motivation, was unknown to the mansasadile. Thus, the mansasadile opposed the egalitarian order of society and simultaneously embodied the ideals of masculinity. Talking about the mansasadile and its lack of remorse, its detachment from kinship obligations and other forces that controlled ordinary people, especially drew my younger, male friends to the mythology surrounding the mansasadile. After all, the mansasadile was all that they were not, but which they hoped, at least in part, to become: namely, independent. And with the sudden growth of paid labour in the farming industry, the possibility was emerging that the young men could actually server themselves from their families. In this sense, the mansasadile was an extreme case, portraying not the opposite of society but rather an inherent potential prowling at the core of the society: the likelihood that the men would reject their obligations when the right opportunity offered itself.

\section{Predators among us}

In the following, I will make an ethnographic leap in order to explore the comparative potential of the idea that I sketched out in the beginning of this article; namely, that monsters may draw their monstrosity from being not a threatening agency intruding into the everyday from the outside, but a radical same erupting out of the ordinary.

The mansasadile provides us with a lens that allows us to see how certain features of the monstrous operate in a Bugkalot context and beyond. Consider, for instance, the 'psychopath'. The concept of the psychopath can be traced back to the German psychiatry of the early $19^{\text {th }}$ century and was popularized by the American psychiatrist Hervey Cleckley in his book The Mask of Sanity (Cleckley 1941). Cleckley was especially concerned with uncovering methods for recognizing the 'psychopath' who hides among us - the anti-social person who pretends to be normal. Cleckley states that this person will be characterized by a superficial charm, a lack of anxiety and guilt, a lack of insight into the impact of his behavior and an inability to form lasting intimate relationships. Interestingly, Cleckley's definition of 
the psychopath makes no mention of physical aggression and willingness to do harm. Those specific features came later. But already at this point we encounter the notion of the hidden, the concealed, the monster that hides behind a mask of sanity. This is the image that gave rise to so many works of fiction in the decades to follow.

Another psychiatrist, Robert D. Hare, who developed the so-called 'psychopathy checklist', elaborated on Cleckley's work and argued that psychopaths are '[social] predators who charm, and ruthlessly plough their way through life, leaving a broad trail of broken hearts, shattered expectations, and empty wallets. Completely lacking in conscience and in feelings for others, they selfishly take what they want and do as they please, violating social norms and expectations without the slightest sense of guilt or regret' (Hare 1999, xi). Here we see the moral vocabulary, which frames the psychopath in terms of inherent evil. This vocabulary is well-known in the media. In my own native country, Denmark, the public is often exposed to the 'psychopathic threat'. Take for instance the opinion piece written by Danish MD and public figure Bente Klarlund for the newspaper Politiken ${ }^{5}$. This piece entitled 'How to spot a psychopath' explains that the 'psychopath' moves among us and poses a real threat at any given time. Furthermore, the article concludes that since the is no treatment for psychopathy (there is no redemption), if you successfully 'identify a psychopath, then run!'

It should be noted that the term 'psychopath', being a famously ill-defined concept, is largely avoided within the Danish psychiatric system. Rather, psychiatrists use the diagnosis 'anti-social personality disorder'. Interestingly, however, when psychiatrists give public talks or appear in the media, they often leave aside the nuances and talk about psychopaths, like Cleckley, as a distinct type of person that moves among us. Most famous in Denmark is the forensic psychiatrist Henrik Day Poulsen who has become a well-known figure in the Danish media by warning people against the evils of psychopaths (e.g. Poulsen 2003). He publishes popular books, travels the country and appears in all the media outlets to tell people, among other things, how they can detect if their partners are psychopaths.

The psychopath gained a particular notoriety as a cultural trope in the yuppie times of neoliberal austerity politics. Patrick Bateman, the meticulously manicured, metropolitan monster in Bret Easton Ellis' American Psycho, became the image of this figure: a shallow subject in pursuit of self-interest - though, like the corporate investors at Wallstreet, without producing anything. Torturing and killing, for Bateman, was entertainment. Bateman became the extreme example of a world in unremitting pursuit of shallow consumption; a monster of its time consisting, as Judith Halberstam (1995) stated about the modern monster, of surfaces and nothing more. Similarly, today, stories are often spread in the media arguing that the percentage of CEO and business leaders who have psychopathic person-

${ }^{5}$ https://politiken.dk/forbrugogliv/sundhedogmotion/sundhedsp/art5478959/Klarlund-Sådan-spotterdu-en-psykopat 
ality disorders are significantly higher than in the rest of the population. ${ }^{6}$ The reason for this, it is being speculated, is that many psychopathic traits are rewarded in business: grandiose sense of self-worth, lack of remorse, impulsivity and risk-taking. ${ }^{7}$

By being severed from ordinary concerns and comportments the psychopath is widely portrayed as an automaton always attempting to satisfy his immediate impulses; a monstrous body-machine beyond choice, ethics and reason. The frightening element, in regards to the psychopaths that we encounter in both fiction and in the news, has to do with the sudden awareness that some individuals roam the world, playing with it, experimenting, though in cruel ways, with people. These individuals do not appear to suffer from the insecurities that the rest of us experience. These stories appeal to the paranoid side of the public, confirming fears of unforeseen predators on the loose. Besides describing (though only on rare occasions) actual encounters with would-be psychopaths, the very general, moral language that surround psychopaths, makes the phenomenon subject to phantasmatic investments that allows the allows that psychopath to become the embodiment of everything that is wrong with society today. The psychopath indexes a certain danger that lies at the core any human relationship, since it is, indeed, impossible to fully know the motives and motivations of people around us.

But more so, the psychopath appears to gain its monstrosity not from being the Other: the figure who through a negative example, a contrast, provides us with a narrative of who we are. We are not dealing with the deviant who, as the sociologist Kai T. Eriksen writes 'supply needed services to society by marking the outer limits of the group experience and providing a point of contrast which gives the norm some scope and dimension' (Eriksen 1966, 20). The psychopath does not first and foremost enable us to talk about common features of the non-monstrous. Rather, what is perhaps truly frightening about this figure is that it is an example though indeed an extreme example - of who we could or need to be. Consider Earl, the stereotypical violent psychopath, played by Brad Pitt in the movie Kalifornia from 1993. He is portrayed with a strange fascination and desire - the camera constantly focusing on his physical appearance. Earl's ruthless, hyper-masculine assertiveness exposes the male protagonist, a writer played by David Duchovny, as a weak, modern man. And as an audience we collectively learn that the only way to overcome the threat posed by Earl, is to emulate him or even become him.

\section{The Outsider Within}

Western fiction has often depicted monsters in various guises. While such monsters, from the outset, become the embodiment of what is foreign, threatening

6 https://www.cnbc.com/2019/04/08/the-science-behind-why-so-many-successful-millionaires-arepsychopaths-and-why-it-doesnt-have-to-be-a-bad-thing.html 
and, in a sense, everything that we are not, we often find that, as the narrative of the book or movies progresses, we come to learn about the monster; we gain insights into its motives, its cruel actions, as not only tied to inherently evil motives but as the consequence of a history, an inner life, in relation to which such actions make sense. In other words, as an audience we come to engage with a primaryethnographical enterprise, grasping the point of view of the Other (Malinowski 2005, 22). Yet, I would maintain that a key element to the emotional impact of horror fiction is the awareness that not only does the monster share the readers humanity - the reader also shares the monster's monstrosity. We learn that the monster emerges not from an ultimately foreign reality, but from certain condition that it shares with us. Monsters lays bare the frail state of the ordinary.

In this article, I have sought to explore how a powerful figure, the mansasadile - a figure of equal amounts of fascination and trepidation - is working within present day storytelling among the Bugkalot. The mansasadile is considered an agency that undermines a form of egalitarianism that revolves around the autonomy of men. While to ordinary men autonomy relies on a public endorsement, the mansasadile transcends this contradiction through its uncompromising detachment. Talking about the mansasadile offers a way to talk about the potential for detaching oneself from other people: to, like the headhunter on an unstoppable killing spree, go into the forest and keep on going. In this sense, the mansasadile becomes an extreme case, portraying not the opposite of Bugkalot society, but rather an inherent potential prowling at the core of the society: that the men would reject their obligations and in fact turn their back on society.

Bruce Kapferer writes that a fear is often expressed within egalitarian societies that the individual will eventually be 'consumed, obscured, and will lose its identity in more inclusive orders and that those who command such orders will negate the autonomy of subordinates' (Kapferer 2012, 15). Certain forces may thereby pose a threat to the integrity of the individual. Kapferer argues that in hierarchical societies, on the other hand, common fears do not concern an emergent, totalizing order; rather, the fear revolves around the monstrous individual - that agent that breaks in from the outside and counteracts the encompassing forces of society by asserting its individuality, thus breaking apart the structure itself.

What is interesting in this respect is that Bugkalot 'fears' seemed to conflate the models: there is a fear of the assertive agency, which is clearly the 'stranger within' that Kapferer identified within egalitarian societies. Yet, this fear did not first and foremost relate to the threat that it posed to society as an engine of encompassment. Rather, by being without fear, the mansasadile was unaffected by the social mechanisms that restrained other men. It thereby threatened to develop hierarchies that would render other men inferior. The mansasadile was just as much an emerging, hierarchical force as the one threatening the egalitarian society - a being who attempted to subvert the hierarchical society by contaminating it with its individualism. The mansasadile shows the situation whereby the monstrous contains 
both components: by both breaking into the social order and emerging from the social order it manifests itself as 'the outsider within'.

My reason for juxtaposing the mansasadile with the psychopath in a Western context is that they each become the extreme realization of particular cultural ideals namely, different types of individualism that are being culturally encouraged. The two characters could thereby be seen as extreme expressions of their time and place. The evoking of the psychopathic threat - even when the medical community has, for the most part, abandoned the diagnosis - involves a particular attempt to address the adverse potentials of our time. This also means, as I have argued, that they should not be considered to be 'Others' in the Orientalist sense, whereby the Other becomes a story of ourselves - as what we are not (Said 1979). The 'extreme same', on the other hand, is the story of what we could become. It is a case that describes us - though indeed an extreme case. But it is not beyond our world and, as with the psychopath, it may indeed be the manipulative nature of every person around us and ourselves. It is the paranoid creation of a system that promotes the exact qualities that the psychopath embodies.

One may speculate that the Bugkalot used the mansasadile as a warning. This, I believe, would only be half of the truth. Just as much, the mansasadile offered a way to talk, expose, and even celebrate the unactualized, monstrous parts of oneself; to show that true autonomy was accessible, within reach. It reminds us that to account for the dynamics of society, one should not merely account for 'what is' but also the emergent stratum of 'what could be'. Thus, to end with a quote by Michael Taussig there 'is only one thing more enchanting than beauty, and that is the capacity to metamorphose into beauty' (Taussig 2012, 14). Perhaps the opposite is also the case: the only thing more monstrous than a monster is the capacity to transform into a monster.

\section{Author Bio}

Henrik Hvenegaard Mikkelsen holds a PhD from the University of Aarhus, Denmark. He has carried out fieldworks in Denmark, Canada (Montreal) and the Philippines, focusing in particular on aging, sexuality, loneliness, violence and politics.

\section{References}

Amnesty International 2017. "Politics of Demonization: Breeding Division and Fear". https://www.amnesty.org/en/latest/news/2017/02/amnesty-international-annual-report-201617/

Asma, Stephen. 2009. On Monsters: An Unnatural History of our Worst Fears. Oxford: Oxford University Press. 
Borneman, John. 2015. Cruel Attachments: The Ritual Rihab of Child Molesters in Germany. Chicago, Il: Chicago University Press. https://doi.org/10.7208/ chicago/9780226234076.001.0001

Boxel, Levi, Matthew Gentzkow and Jesse Shapiro. 2020. "Cross-country trends in affective polarization." SIEPR working paper no. 20-004.

Bubandt, Nils. 2014. The Empty Seashell: Witchcraft and Doubt on an Indonesian Island. Ithaca: Cornell University Press. https://doi.org/ $\underline{10.7591 / 9780801471971}$

Bubandt, Nils and Rane Willerslev. 2015. "The Dark Side of Empathy: Mimesis, Deception, and the Magic of Alterity." Comparative Studies in Society and History 57(1):5-34. https://doi.org/10.1017/S0010417514000589

Cleckely, Hervey. 1941. The Mask of Sanity: An Attempt to Clarify Some Issues About the So-Called Psychopathic Personality. Maryland Heights: Mosby

Comaroff, Jean and John Comaroff. 1999. "Occult Economies and the Violence of Abstraction: Notes from the South African Postcolony." American Ethnologist 26(2): 279-303.

Comaroff, Jean and John Comaroff. 2002. "Alien-Nation: Zombies, Immigrants, and Millennial Capitalism." South Atlantic Quarterly 101(4): 779-805. https://doi.org/10.1525/ae.1999.26.2.279

Carothers, Thomas. and Andrew O'Donohue. 2019. Democracy Divided: The Global Challenge of Political Polarization. Washington: Brookings Institution Press.

Chamberlain, Edward. 2019. "Rethinking the Monstrous: Gender, Otherness, and Space in Cinematic Storytelling of Arrival and the Shape of Water." Comparative Litterature \& Culture 21(7): 1-11. https://doi.org/ $\underline{10.7771 / 1481-4374.3666}$

Eriksen, Kai T. 1966. Wayward Puritans: A Study in the Sociology of Deviance. New York: John Wiley.

Evans-Pritchard, Evan. 1937. Witchcraft, Oracles and Magic among the Azande. Oxford: Clarendon Press.

Geschiere, Peter. 1998. "Globalization and the Power of Indeterminate Meaning: Witchcraft and Spirit Cults in Africa and East Asia." Development and Change 29(4): 811 -837. https://doi.org/10.1111/1467-7660.00100 
Henrik Hvenegaard Mikkelsen - Out of the Ordinary

Geschiere, Peter. 2013. Witchcraft, Intimacy, and Trust: Africa in Comparison. Chicago, IL: University of Chicago Press. https://doi.org/10.7208/chicago/ $\underline{9780226047751.001 .0001}$

Graeber, David. 2005. Fragments of an Anarchist Anthropology. Chicago: Prickly Paradigm.

Halberstam, Judith. 1995. Skin Shows: Gothic Horror and the Technology of Monsters. Durham: Duke University Press. https://doi.org/10.2307/j.ctv1220pqp

Hare, Robert D. 1993. Without Conscience: The Disturbing World of the Psychopaths among Us. New York: The Guilford Press

Kapferer, Bruce. 1983. A Celebration of Demons: Exorcism and the Aesthetics of Healing in Sri Lanka. Bloomington: Indiana University Press.

Kapferer, Bruce. 2012. Legends of People, Myths of State: Violence, Intolerance and Political Culture in Sri Lanka and Australia. Washington D.C.: Smithsonian Institution Press.

Kuldova, Tereza. 2017. "The Sublime Splendor of Intimidation: Outlaw Biker Aesthetics of Power. Visual Anthropology 30(5): 379-402. https://doi.org/ $\underline{10.1080 / 08949468.2017 .1371545}$

Lee, Richard. 1969. "Eating Christmas in the Kalahari." Natural History 1-4.

Lee, Richard. 1988. "Reflections on Primitive Communism." In Hunters and Gatherers 1. Edited by T. Ingold, D. Riches, and J. Woodburn. Oxford: Berg. $242-68$.

Lee, Richard. 2003. The Dobe Fu/'hoansi. Belmont, CA: Wadsworth.

Mikkelsen, Henrik H. 2018. Cutting Cosmos: Masculinity and Spectacular Events Among the Bugkalot. New York: Berghahn. https://doi.org/10.2307/j.ctvw04cc3

Mikkelsen, Henrik H. 2017. Facehunting: Empathy, masculinity and violence among the Bugkalot. Fournal of Extreme Anthroology 1(3): 1-13. https:// doi.org/10.5617/jea.4877

Mikkelsen, Henrik H. 2016. "Chaosmology: Shamanism and personhood among the Bugkalot." Hau: Journal of Ethnographic Theory 6(1): 189-205. https:// doi.org/10.14318/hau6.1.013

Mikkelsen, Henrik H. 2013. Defacing Death: Commencing Time and the Materiality of the Man among the Bugkalot. In Death, Materiality and the Origin of 
Henrik Hvenegaard Mikkelsen - Out of the Ordinary

Time, vol. 1, edited by R. Willerslev and D. Refslund. Farnham: Ashgate. 231-248.

Mikkelsen, Henrik H., and Thomas F. Søgaard. 2015. "Violent Potentials: Exploring the Intersection of Masculinity and Violence among the Bugkalot." NORMA 10(3-4): 281-94. https://doi.org/ $\underline{10.1080 / 18902138.2015 .1102383}$

Mubarki, Meraj. 2014. "The Monstrous 'Other' Feminine: Gender, Desire and the 'Look' in the Hindi Horror Genre." Indian Fournal of Gender Studies 21(3): 379-399. https://doi.org/10.1177/0971521514540708

Musharbash, Yasmine. 2014. "Introduction: Monsters, Anthropology, and Monster Studies." In Monster Anthropology in Australia and Beyond, edited by M. Musharbash and G. Presterudstuen. London: Palgrave Macmillan. https://doi.org/10.1057/9781137448651

Poulsen, Henrik Day. 2014. "Hverdagens Psykopater: Mennesker der Skader Andre [Everyday Psychopaths: People Who Hurt Others]". København: Forlaget Liva.

Rosaldo, Michelle. 1980. Knowledge and Passion: Ilongot Notions of Self and Social Life. Cambridge: Cambridge University Press.

Rosaldo, Michelle. 1983. "The Shame of Headhunters and Autonomy of Self." Ethos 11(3): 135-51. https://doi.org/10.1017/CBO9780511621833

Said, Edward. 1979. Orientalism. New York: Vintage Books.

Stevens, Phillips 2008. "Universal Cultural Elements in the Satanic Demonology". In Encyclopedic Sourcebook of Satanism, edited by J.R. Lewis and J.A. Petersen. Amherst, NY: Prometheus Books. 264-273.

Taussig, Michael. 2012. Beauty and the Beast. Chicago: University of Chicago Press. https://doi.org/10.7208/chicago/9780226789880.001.0001

Turner, V. 1967. "Betwixt and Between: The Liminal Period in Rites de Passage." in The Forest of Symbols: Aspects of Ndembu Ritual. Cornell University Press. 93-111.

Žižek, Slavoj. 2012. "Living in the Time of Monsters. In Critical Pedagogy in the New Dark Ages, edited by M. Nikolakaki. New York: Peter Lang. 32-44. 